\title{
カテーテルアブレーションと抗凝固療法
}

奥村 謙*

\section{Catheter ablation and anticoagulation therapy}

\author{
Ken OKUMURA
}

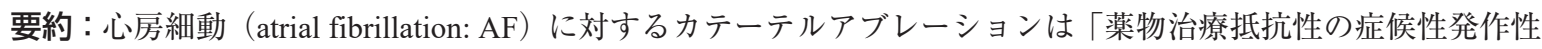
$\mathrm{AF} 」$ に対してクラス I適応, 「症候性持続性 $\mathrm{AF} 」 に$ 対してクラス IIa 適応で, 施行数は年々増加している. $\mathrm{AF}$ アブレーションは, $\mathrm{AF}$ 自体に血栓塞栓リスクがあり, 左房内に長時間カテーテルを留置, 広範囲に焼灼または 冷凍するため, 血栓塞栓の発生リスクを伴う。また複数の電極カテーテルを心腔内まで進め, 心房中隔穿刺や 左房内で比較的複雑なカテーテル操作を必要とするため, 心夕ンポナーデなどの出血りスクを伴う。すなわち 高塞栓・高出血リスクの治療手技であり, 周術期の適切な抗凝固管理が必要となる. 抗凝固薬はワルファリン から直接経口抗凝固薬へとシフトし, その管理は容易となるとともにアブレーションの術直前, 術後の投与法 に関しても，最近多くのエビデンスが示されている，適切な抗凝固薬管理により，安全なアブレーション施術 が可能となっている.

Key words: Atrial fibrillation, catheter ablation, anticoagulation therapy, warfarin, direct oral anticoagulant

\section{はじめに}

心房細動（atrial fibrillation: AF）に対するカテーテ ルアブレーションの進歩には目覚ましいものがあり, わが国でもアブレーション施行件数が年々増加 ${ }^{1,2)}$, 近い将来年間 10 万件にも達すると予測される. 治療 成績の向上とともに, 最近のコホート研究, レジス トリー研究の結果では, アブレーション施行群は非 施行群に比して, 脳梗塞発症率のみでなく死亡率も 低下することが示された ${ }^{3)}$. 重症心不全例を対象と した無作為化比較試験の結果では, アブレーション は心不全入院とともに死亡率を低下させた ${ }^{4)}$. 脳梗 塞既往例に対する二次予防においても, 脳梗塞既往 を有する 47 例 [77\%は直接経口抗凝固薬 (direct oral anticoagulant: DOAC) 服用] と有さない 400 例（77\% は DOAC 服用）に対する我々のアブレーションの効 果の検討では, 急性期合併症, 長期再発予防効果に

*責任者連絡先：

済生会熊本病院循環器内科

干 861-4193 熊本市南区近見 5-3-1

Tel: 096-351-8000, Fax: 096-351-8513

E-mail: okumura@hirosaki-u.ac.jp
差はなく, 平均 14 ケ月の経過観察中に両群とも脳梗 塞発症を認めなかった ${ }^{5)}$. $\mathrm{AF}$ アブレーションは, と くに発作性 $\mathrm{AF}$, 持続期間 1 年以内の持続性 $\mathrm{AF}$ 例に は効果が高く, 生命予後, 機能予後の観点からも積 極的に適応を検討すべきだろう。

\section{AF アブレーションと周術期抗凝固療法}

$\mathrm{AF}$ アブレーションの適応, 術式, 成績, 合併症等 の詳細は最新のガイドライン等を参照されたいが ${ }^{1)}$, 手技の面からは高出血および高塞栓リスクのイン ターベンションに位置づけられる ${ }^{1)}$. 出血リスクに 関しては, 左房内に複数のカテーテルを留置するた め, 血栓塞栓症予防のために比較的大量のへパリン 投与を必要とすること（活性化凝固時間を 300 秒以 上に維持), カテーテル手技が比較的に複雑で, 心臓 壁損傷, 心夕ンポナーデのリスクがあること, 血管 穿刺に伴い穿刺部での出血, 血腫形成等が起こりう ること, などが挙げられる. 心タンポナーデがとく に重篤で，発生頻度は約 $1 \%$ である ${ }^{1,6)}$. 塞栓症に関 しては, $\mathrm{AF}$ 自体が血栓塞栓症リスクであり, 左房内 カテーテル留置および焼灼または冷凍に伴う心内膜 
表 1 心房細動（AF） アブレーション周術期の抗凝固療法の推奨とエビデンスレベル.

\begin{tabular}{|c|c|c|c|c|}
\hline & $\begin{array}{l}\text { 推罢 } \\
\text { クラス }\end{array}$ & $\begin{array}{l}\text { エビデンス } \\
\text { レベル }\end{array}$ & $\begin{array}{c}\text { Minds } \\
\text { 推摆 } \\
\text { グレード }\end{array}$ & $\begin{array}{c}\text { Minds } \\
\text { エビデンス } \\
\text { 分類 }\end{array}$ \\
\hline $\begin{array}{l}\text { 持続性 } \mathrm{AF} \text { および高リスク例（CHADS }{ }_{2} \text { スコア } 2 \text { 点以上）では, ワルファリンあるいは } \\
D O A C \text { を, 少なくとも } 3 \text { 週間以上使用すべきである }\end{array}$ & Ila & $C$ & C1 & VI \\
\hline $\begin{array}{l}\text { ワルファリンもしくはダビガトランによる抗㠜固療法が行われている患者では，休薬なしで } \\
\text { AF アブレーションを施行することが推奖される }\end{array}$ & I & A & A & I \\
\hline $\begin{array}{l}\text { リバーロキサバン, アピキサバンによる抗凝固療法が行われている患者では, 休薬なしで AF } \\
\text { アブレーションを施行することが推奨される }\end{array}$ & Ila & B & B & II \\
\hline $\begin{array}{l}\text { エドキサバンによる抗凝固療法が行われている患者では，休薬なしでAFアブレーションを } \\
\text { 施行することは合理的である }\end{array}$ & Ila & B & B & III \\
\hline $\begin{array}{l}\text { DOACによる抗凝固療法が行われている患者では. AFアブレーション施行前に抗凝固薬を } \\
\text { 1もしくは } 2 \text { 回休薬し. アブレーション後に再開することが推奨される }\end{array}$ & Ila & B & B & II \\
\hline $\begin{array}{l}\text { ヘハリンは, 鼠径部穿刺後あるいは心房中隔穿刺後に至適用量をボーラス投与し．アブレー } \\
\text { ション手技中は ACT值を } 300 \text { 秒以上に維寺する }\end{array}$ & I & B & B & III \\
\hline $\begin{array}{l}\text { 術後の抗㠜固療法 (ワルファリンあるいは DOAC) は, 再発の有無にかかわらず, 少なくと } \\
\text { も3カ月間継続することが推奨される }\end{array}$ & Ila & $C$ & C1 & VI \\
\hline $\begin{array}{l}\text { 術後 } 3 \text { カ月以降の抗凝固療法（ワルファリンあるいは DOAC）に関しては, 長期経過観察期 } \\
\text { 間中の AF 再発を考虑し、. CHADS } 2 \text { スコア } 2 \text { 点以上の患者では継続投与することが焦ましい }\end{array}$ & Ila & $C$ & C1 & VI \\
\hline
\end{tabular}

日本循環器学会, 日本不整脈心電学会. 不整脈非薬物治療ガイドライン（2018 年改訂版）https://www.j-circ.or.jp/cms/wpcontent/uploads/2018/07/JCS2018_kurita_nogami191120.pdfから引用（2019年 4 月閲覧）

損傷により血栓形成のリスクが生じること，とくに 高周波通電ではカテーテル先端に微小凝血塊が形成 されるリスクがあること, 持続性 $\mathrm{AF}$ では洞調律復 帰後も心房収縮の回復に時間を要すること, などが 要因となる. 術後の脳梗塞・TIA の発症頻度は $0.4 \%$ 前後である ${ }^{1,6)}$.

出血リスクに対しては, 術中ヘパリン管理と慎重 なカテーテル操作等でその低減を図る。一方, 塞栓 症リスク低減のためには周術期に適切な抗凝固療法 を継続実施する必要があり，これにより手技に伴う 出血リスクが増大する。わが国の「不整脈非薬物治 療ガイドライン (2018 年改訂版) 」 ${ }^{1)}$ は, 塞栓症リス クを低減するため,「持続性 AF および高リスク例 ( $\mathrm{CHADS}_{2}$ スコア 2 点以上) では, ワルファリンある いはDOACを, 少なくとも 3 週間以上使用すべきで ある (クラス IIa)」, さらに「術後の抗凝固療法（ワ ルファリンあるいはDOAC）は, 再発の有無にかか わらず，少なくとも 3 ケ月間継続することが推奨さ れる(クラス IIa)」と記載している $\left(\right.$ 表 1) ${ }^{1}$. 以下 にアブレーション周術期における各抗凝固薬の有効 性, 安全性に関するエビデンスを概説する.

\section{2. 各抗凝固薬のエビデンス}

1）ワルファリン

以前は唯一の経口抗凝固薬であり, 周術期にはワ ルファリンが投与された。 ただし，心タンポナーデ 等の出血性合併症が発症した場合, ワルファリンの 迅速な中和は困難なため（現在は凝固因子補充療法 が使用可能), 心囊穿刺のみでは不十分で, 外科的処 置が必要となるケースもあった. そのため, アブレー ション手技の 2～5 日前からワルファリンを中断し， ヘパリンに置換する「ヘパリンブリッジ」が行われ た.しかし，ワルファリン中断群と継続したままア ブレーションを行う継続群の間で周術期出血性合併 症に差がないことが報告され7,8), さらにメ夕解析で はワルファリン継続でアブレーションを行うことに より, 脳梗塞・TIA と小出血が有意に減少し〔ハザー ド比（HR）はそれぞれ 0.1 および 0.38]，一方で心 タンポナーデを含めた大出血は増加しない（HR = 0.67) ことが示された ${ }^{9)}$. 中和郕 (凝固因子補充療法) が適応となったこともあり, 現在はワルファリン継 続がクラス 1 適応 (レベル A) となっている $(\text { 表 1 })^{1)}$. 慢性腎不全・慢性透析例に対する抗凝固療法：日 
本透析医学会ガイドラインはワルファリンを原則禁 忌としており, 必要な場合も PT-INR $<2.0$ に維持す ることが望ましいと記載している ${ }^{10)}$. 一方, DOAC は禁忌であり, ワルファリン以外の経口薬はなく, 慎重な導入と維持が必要となる。筆者は PT-INR 2.0 前後を目標とし，術前に経食道心エコー（TEE）で 血栓のないことを確認し，アブレーションを実施し ている. 術後は 2 ヶ月以内に中止することが多い.

\section{2) DOAC}

ダビガトラン（トロンビン阻害薬）が上市され 9 年以上が経過したが，現在ではリバーロキサバン， アピキサバン，エドキサバン（以上 Xa 阻害薬）の 合計 4 種類の DOAC が使用可能で, 非弁膜症性 AF 例の血栓塞栓症予防の標準的治療薬となっている. ワルファリンと比較し, 効果発現が速く（rapid onset), 消失も速い（rapid offset）という特徵があ $\eta^{11)}$, 術前 3 週間（以上）という比較的短期間前か ら開始しても速やかに効果が得られ，周術期管理が 容易となる. 周術期の有効性, 安全性がワルファリ ンと同等またはそれ以上であれば, DOACはアブ レーションにより適した薬剤と考えられる.

ではDOAC は継続すべきだろうか，あるいは中断 すべきだろうか. ダビガトランには特異的中和剤が 使用可能であるが, Xa 阻害薬には中和剤がなく, 継 続したままアブレーション手技を行うと, 出血性合 併症が生じた場合に止血困難となる可能性がある. 一方, 術当日のみ投薬を中断することは短期間でも あり, 可能と思われるが, 八イリスク例では血栓塞 栓症が懸念されるかもしれない。また投与再開の夕 イミングも問題となる. 各 DOAC の周術期投与法に 関する最近の試験結果を以下に述べる.

(1) ダビガトラン

2017 年の RE-CIRCUIT 試験で, 周術期ダビガトラ ン継続投与（317 例， $150 \mathrm{mg}$ を 1 日 2 回投与）とワ ルファリン継続投与（318例, PT-INR2.0～3.0) の有 効性, 安全性が比較検討された ${ }^{12)}$. その結果, ダビ ガトラン群は心タンポナーデ (1 件対 6 件) を含め た ISTH 基準大出血の出現頻度がワルファリン群よ り有意に少なく（HR $=0.22, \mathrm{P}<0.001 ）$ ， また塞栓 症は両群ともに極めて少なかった（ワルファリン群 でTIA 1 例のみ) (図 1, 左から 2 列目) ${ }^{13)}$. 大出血発
現の推移を見ると（図 2), 術中, 術直後のみでな く, 経過中もワルファリン群で増加, ダビガトラン 群では消化管出血 1 例のみであった. ダビガトラン はワルファリンより安全性に優れることが示された が, 下記のようにイダルシズマブで中和可能であり, 周術期抗凝固薬としてはダビガトランが望ましいと 言える。これを反映し，ガイドラインでもクラス I 適応（レベルA）に位置づけられている $(\text { 表 1 })^{1)}$. 一方, わが国からの報告で, ダビガトランの最小の中 断（術前 1 2 回のスキップ）は, ワルファリン継続 に比して塞栓症を増加させず, 出血性合併症は減少 したことが示された (ABRIDGE-J 試験 $)^{14)}$. 少なくと も術直前の投与はスキップしてもいいかもしれない.

注意点は, クレアチニンクリアランス $(\mathrm{CCr})$ が $50 \mathrm{~mL} /$ 分未満の中等度腎機能低下例や 70 歳以上の 高齢者では $110 \mathrm{mg} 1$ 日 2 回が投与されることが多い が, RE-CIRCUIT 試験と同様の結果が得られるかは 不明である. AF アブレーションは 75 歳以上の高齢 者でも多く行われており, ダビガトランの対象患者 の選定には注意を要する.ささら 1 日 2 回の服薬が 必要であり, 周術期のアドヒアランスを徹底しなけ ればならない.

ダビガトラン中和剤イダルシズマブ：DOACの半 減期は比較的に短く $(10 \sim 12$ 時間), 出血性合併症 の多くは圧迫止血などで対応可能である。しかし， 服薬中の頭蓋内出血, 消化管出血, 緊急手術等に際 しては, 中和剤が使用可能なことが望ましい. イダ ルシズマブはダビガトラン特異的中和剤で, その有 用性は REVERSE-AD 試験で前向きに検証され ${ }^{15)}$, ダビガトランの効果が迅速, 完全, 持続的に中和さ れることが確認され, 一方, 投与 (静注) 自体の凝

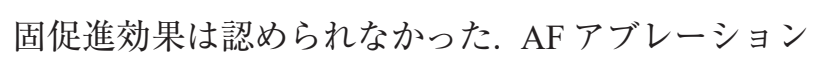
に伴い発生した心タンポナーデ等の重大出血性合併 症に対し，イダルシズマブ投与により有効かつ安全 に止血可能であったことがわが国から報告されて いる 16).

(2)リバーロキサバン

2015 年の VENTURE-AF 試験で, 少数例ではある ものの, 周術期リバーロキサバン継続群 [114 例, 1 日 1 回 $20 \mathrm{mg}$ (海外用量) の夜間投与を推奨］とワ ルファリン継続群（107例）が比較検討された ${ }^{17)}$. 


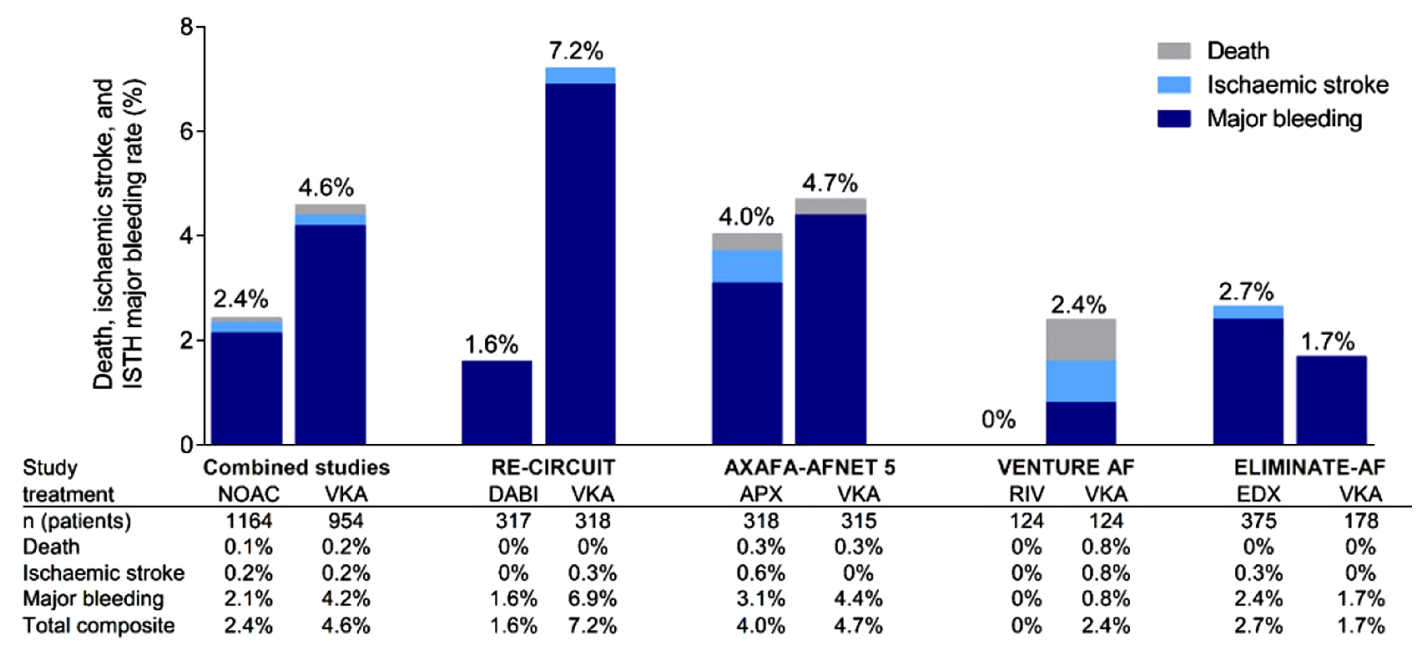

図 1 RE-CIRCUIT 試験, AXAFA-AFNET 5 試験, VENTURE-AF 試験, ELIMINATE-AF 試験の DOAC 継続群とワルファリ ン継続群のイベント発生率 (死亡, 脳梗塞, 大出血). 図左端列 (Combined studies) は 4 試験のイベント発生率平均

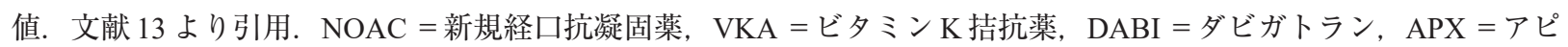
キサバン， RIV = リバーロキサバン， EDX =エドキサバン

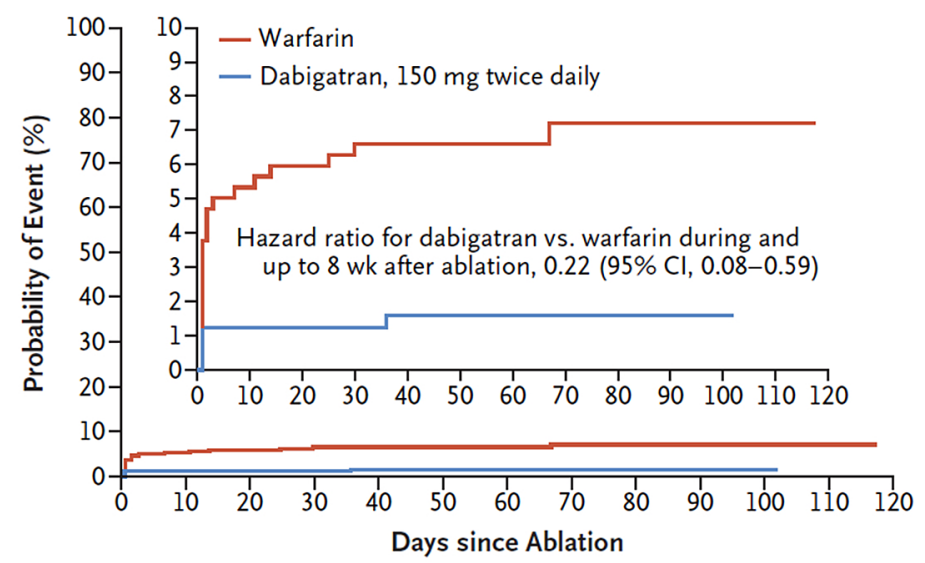

No. at Risk

$\begin{array}{lllllllllrllll}\text { Dabigatran } & 317 & 313 & 311 & 311 & 306 & 305 & 297 & 83 & 4 & 2 & 1 & 0 & 0 \\ \text { Warfarin } & 318 & 301 & 297 & 296 & 295 & 295 & 278 & 85 & 13 & 5 & 3 & 1 & 0\end{array}$

図 2 RE-CIRCUIT 試験におけるワルファリン継続群とダビガトラン継続群の大出血発現の推移. 文献 12 より引用.

その結果, ISTH 基準の重大出血性イベント（各々 0 例, 1 例), 塞栓症イベント (各々 0 例, 2例) の発 生は両群間ともに極めて低く，またすべての出血性 イベントも各々 21 例, 18 例で同等であった（図1, 右から 2 列目 $)^{13)}$. この試験では, リバーロキサバン は夜間に投与され, 従って術中にはリバーロキサバ ン血中濃度は低くなっていたと考えられ，アブレー ション手技はリバーロキサバンに影響されず実施可 能であったと推察される. わが国のガイドラインで
は, 検討症例数が少ないこと, 投与量が異なること, 中等度以上の腎機能低下例は除外されたことなどに より, 特異的中和剤がないことより, リバーロキサ バン継続投与はクラス IIa 適応（レベル B ）に位置づ けられている $(\text { 表 } 1)^{1)}$.

わが国ではアブレーション 3 週間以上前からリ バーロキサバン（1118 例, JACRE-R 群）またはワル ファリン（204 例, JACRE-W 群, 継続投与) が投与 された症例を前向きに登録したJACRE 研究が実施 


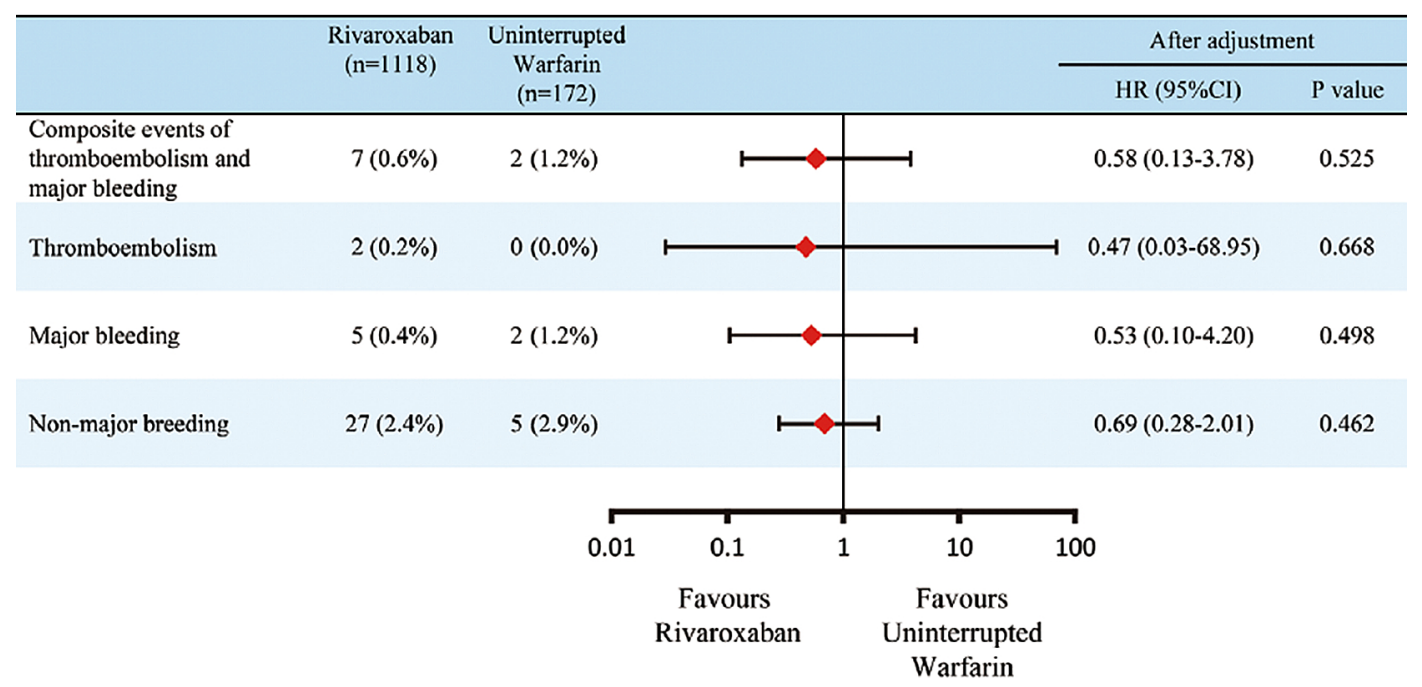

図 3 JACRE 試駼結果. リバーロキサバン群とワルファリン群（継続）におけるイベント発生率の比較. 文献 18 よ引用.

された ${ }^{17)}$. JACRE-R 群でのアブレーション開始から 30 日間の血栓塞栓症は 2 例 $(0.2 \%)$, 重大出血 (ISTH 基準) は 5 例 $(0.4 \%)$ で，複合イベント発生率は 7 例 $(0.6 \%)$ であった.一方, JACRE-W 群では, 血栓 塞栓症は 0 例 $(0 \%)$, 重大出血は 3 例 $(1.5 \%)$ で あった. Cox 回帰モデル（Firth’s correction）で比較 検討すると, 2 群間で差は認められなかった（図3). なお JACRE-R 群のほとんどに対してアブレーション 前日までと翌日からはリバーロキサバン投与が行わ れ，アブレーション術日には $42 \%$ のに投与され， その多く (38\%) は術後であった ${ }^{18)}$. しかし，血栓 塞栓症発現率は $0.2 \%$ と低く, 双方とも TIA であっ た. 1 日 1 回のリバーロキサバンの術当日の投与に ついては, 中和剤のないことを考慮し, スキップま たは術後に投与しても影響は少ないことが示唆さ れた。

(3) アピキサバン

2018 年の AXAFA-AFNET 5 試験で, アピキサバン 継続群（318 例，1日2 回投与）とワルファリン継続 群 (315 例) の有効性, 安全性が比較検討された ${ }^{19)}$. その結果, 複合エンドポイント（死亡, 脳卒中, BARC 基準 2-5 の出血）がアピキサバン群で 22 例 (6.9\%), ワルファリン群で 23 例 $(7.3 \%)$ に認められ, 両群間に差はなかった（非劣性 $\mathrm{P}=0.0002 ） （$ 図 1, 中央列 $)^{13)}$. ISTH 基準大出血は, アピキサバン群で は 10 例 $(3.1 \%)$, ワルファリン群では 14 例 $(4.4 \%)$
に認められた，以上より，アピキサバン継続もワル ファリン継続と同等の有効性, 安全性が確認された. わが国からもアピキサバン継続投与の有用性が報告 され ${ }^{20)}$, アピキサバン継続投与はクラス IIa 適応 (レ ベル B）に位置づけられている (表 1) ${ }^{1)}$ 。 なおアピ キサバンには現時点では特異的中和剤はなく, 術当 日の朝の投与をスキップし, 術後に止血確認後, 投 与してもよいと思われる〔クラス IIa 適応（レベル B)] (表 1 $)^{1)}$.

(4)エドキサバン

2019 年の ELIMINATE-AF 試験で, エドキサバン 継続（411例，1日 1 回夜間投与）とワルファリン継 続［203例（2:1で割り付け）］の有効性, 安全性が 比較検討された ${ }^{13)}$. その結果, 大出血に差はなく (2.5\%対 $1.5 \%)$, 脳梗塞をエドキサバン継続群で 1 例に認めたのみであった (図 1, 右端列 ${ }^{13)}$ 。他の DOAC とほぼ同様の結果で, ガイドラインではエド キサバン継続投与はクラス IIa 適応（レベル B ）に位 置づけられている $\left(\right.$ 表 1) ${ }^{1}$.

上記の VENTURE-AF 試験（リバーロキサバン $)^{17)}$

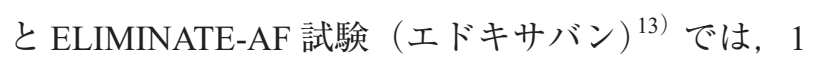
日 1 回投与の DOAC が夜間（夕食後）に投与され, アブレーションの直前には投与されなかった．Xa阻 害薬には特異的中和剂は使用できず, 安全性の観点 からは手技直前の投与は好ましくないだろう。この 手技前非投与の有効性・安全性を前向きに検証する 


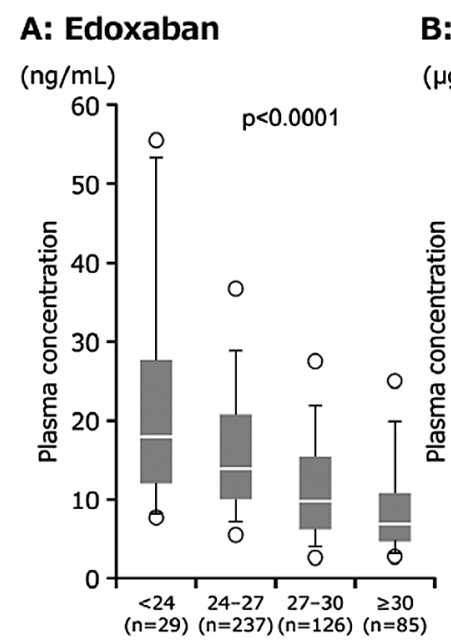

B: D-dimer $(\mu \mathrm{g} / \mathrm{mL})$

\section{C: $\mathbf{F} \mathbf{1 + 2}$}

$(\mathrm{pmol} / \mathrm{L})$

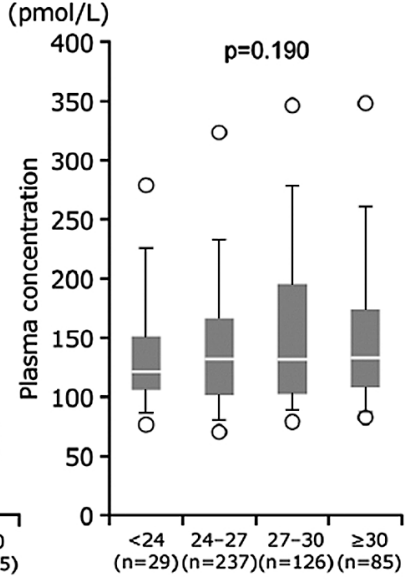

Time from last administration of edoxaban to start of CA (hours)

図 4 KYU-RABLE 試験におけるエドキサバン最終投与からアブレーション開始までの時間とエドキサバン血中濃度（A） および凝固マーカー值 $[\mathrm{D}-\operatorname{dimer}(\mathrm{B})$ および F1+2 $(\mathrm{C})]$ の関連. 文献 21 より引用. $\mathrm{CA}=$ カテーテルアブレーショ ン.

目的で, KYU-RABLE研究がわが国で実施された ${ }^{21)}$. 本研究のプロトコールは, 朝 1 回投与のエドキサバ ンをアブレーション前日まで継続し，術当日は手技 終了後 (止血確認後) 4 時間で投与し（遅延投与), 翌日からは通常投与を行うというもので，国内の多 くの施設で取り入れられていた DOAC 投与プロト コールが検証された。 513 例が登録され，術中術後 の血栓塞栓症の発生はなく $(0 \%)$, 大出血（心夕ン ポナーデ）を 1 例（ $0.2 \%)$ に認めたのみであった (穿刺排液で治療され輸血は行われなかった)。本研 究では, アブレーション直前にエドキサバン血中濃 度と凝固マーカー（D-dimer およびF1+2）が測定さ れた $(\text { 図 4 })^{21)}$ 。エドキサバン最終投与からの時間が 長くなるほどエドキサバン血中濃度は低下したが, 凝固マーカーの増加は認めなかった。短時間（12 時 間以内）の投与遅延は凝固系の賦活化には至ってい ず，本プロトコールの妥当性が支持された。

以上の 4つの臨床試験の DOAC 継続群とワルファ リン継続群のイベント発生率 (死亡, 脳梗塞, 大出 血）をまとめた結果（平均值）を図 1 左端列に示 $す^{13)}$. 全体のイベント発生率は DOAC 継続群がワル ファリン継続群より低值で, DOAC 継続療法の有用 性が示された。一方，アブレーション直前の投与を 術後に遅延投与するか 1 日スキップすることは塞栓
症リスクの増加に必ずしも繋がらない. DOACのア ブレーション術日 1 日の休薬（スキップ）は, 継続 投与群と比較して有効性, 安全性において差がなかっ たことがわが国から報告されている22)。ダビガトラ ン以外は中和剤がない状況では, とくにXa阻害薬 については遅延投与（またはスキップ）がより安全 と考えられる。

著者の利益相反 $(\mathrm{COI})$ の開示 :

講演料・原稿料など（第一三共, 日本ベーリンガー インゲルハイム, ブリストルマイヤーズスクイブ, ジョンソンエンドジョンソン), 臨床研究 (治験)（第 一三共)

\section{文献}

1) 循環器病の診断と治療に関するガイドライン：不整脈非 薬物治療ガイドライン（2018 年改訂版）https://www. j-circ.or.jp/cms/wp-content/uploads/2018/07/JCS2018_kurita nogami191120.pdf（2020 年 8 月閲覧）

2) 日本循環器学会: 循環器疾患診療実態調査 (2019年度年 報告書）http://www.j-circ.or.jp/jittai_chosa/jittai_chosa2018web.pdf（2020 年 8 月閲覧）

3) Friberg L, Tabrizi F, Englund A: Catheter ablation for atrial fibrillation is associated with lower incidence of stroke and death: Data from Swedish health registries. Eur Heart J 37: 2478-8247, 2016.

4) Marrouche NF, Brachmann J, Andresen D, Siebels J, Boersma L, Jordaens L, Merkely B, Pokushalov E, Sanders P, Proff J, 
Schunkert H, Christ H, Vogt J, Bänsch D; CASTLE-AF Investigators: Catheter ablation for atrial fibrillation with heart failure. N Engl J Med 378: 417-427, 2018.

5) Nishizaki K, Itoh T, Kimura M, Tsushima Y, Shoji Y, Kinjo T, Ishida Y, Sasaki K, Horiuchi D, Sasaki S, Tomita H, Okumura $\mathrm{K}$ : Safety and efficacy of contemporary catheter ablation for atrial fibrillation patients with a history of cardioembolic stroke in the era of direct oral anticoagulants. J Cardiol 70: 86-91, 2017.

6) Inoue K, Murakawa Y, Nogami A, Shoda M, Naito S, Kumagai K, Miyauchi Y, Yamane T, Morita N, Mitamura H, Okumura K: National survey of catheter ablation for atrial fibrillation: The Japanese catheter ablation registry of atrial fibrillation (J-CARAF). J Arrhythmia 29: 221-227, 2013.

7) Di Biase L, Burkhardt JD, Mohanty P, Sanchez J, Horton R, Gallinghouse GJ, Lakkireddy D, Verma A, Khaykin Y, Hongo R, Hao S, Beheiry S, Pelargonio G, Dello Russo A, Casella M, Santarelli P, Santangeli P, Wang P, Al-Ahmad A, Patel D, Themistoclakis S, Bonso A, Rossillo A, Corrado A, Raviele A, Cummings JE, Schweikert RA, Lewis WR, Natale A: Periprocedural stroke and management of major bleeding complications in patients undergoing catheter ablation of atrial fibrillation: The impact of periprocedural therapeutic international normalized ratio. Circulation 121: 2550-2556, 2010.

8) Hakalahti A, Uusimaa P, Ylitalo K, Raatikainen MJP: Catheter ablation of atrial fibrillation in patients with therapeutic oral anticoagulation treatment. Europace 13: 640645, 2011.

9) Santangeli P, Di Biase L, Horton R, Burkhardt JD, Sanchez J, Al-Ahmad A, Sanchez J, Al-Ahmad A, Hongo R, Beheiry S, Bai R, Mohanty P, Lewis WR, Natale A: Ablation of atrial fibrillation under therapeutic warfarin reduces periprocedural complications: Evidence from a meta-analysis. Circ Arrhythm Electrophysiol 5: 302-311, 2012.

10) 社団法人日本透析医学会：血液透析患者における心血管 合併症の評価と治療に関するガイドライン。透析会誌 44: 337-425, 2011.

11) 循環器病の診断と治療に関するガイドライン：不整脈薬 物治療ガイドライン（2020 年改訂版）https://www.j-circ. or.jp/cms/wp-content/uploads/2020/01/JCS2020_Ono200619 .$p d f(2020$ 年 3 月閲覧)

12) Calkins H, Willems S, Gerstenfeld EP, Verma A, Schilling R, Hohnloser SH, Okumura K, Serota H, Nordaby M, Guiver K, Biss B, Brouwer MA, Grimaldi M; RE-CIRCUIT Investigators: Uninterrupted dabigatran versus warfarin for ablation in atrial fibrillation. N Engl J Med 376: 1627-1636, 2017.

13) Hohnloser SH, Camm J, Cappato R, Diener HC, Heidbüchel H, Mont L, Morillo CA, Abozguia K, Grimaldi M, Rauer H, Reimitz PE, Smolnik R, Mönninghoff C, Kautzner J: Uninterrupted edoxaban vs. vitamin $\mathrm{K}$ antagonists for ablation of atrial fibrillation: The ELIMINATE-AF trial. Eur Heart J 40: 3013-3021, 2019.

14) Nogami A, Harada T, Sekiguchi Y, Otani R, Yoshida Y, Yoshida K, Nakano Y, Nuruki N, Nakahara S, Goya M, Origasa H, Kihara Y, Hirao K, Aonuma K; ABRIDGE-J (ABlation peRIoperative DabiGatran in use Envisioning in Japan) Investigators: Safety and efficacy of minimally interrupted dabigatran vs uninterrupted warfarin therapy in adults undergoing atrial fibrillation catheter ablation: A randomized clinical trial. JAMA Netw Open 2: e191994, 2019.

15) Pollack CV Jr, Reilly PA, Eikelboom J, Glund S, Verhamme P, Bernstein RA, Dubiel R, Huisman MV, Hylek EM, Kamphuisen PW, Kreuzer J, Levy JH, Sellke FW, Stangier J, Steiner T, Wang B, Kam CW, Weitz JI: Idarucizumab for dabigatran reversal. N Engl J Med 373: 511-520, 2015.

16) Okishige $K$, Yamauchi $Y$, Hanaki $Y$, Inoue $K$, Tanaka N, Yamaji H, Murakami T, Manita M, Tabata K, Ooie T, Tatsukawa Y, Sakai H, Yamaki M, Murakami M, Takada T, Osaka Y, Ono Y, Handa K, Sugiyama K, Yoshizawa T, Fukaya H, Tashiro H, Takase S, Harada M, Watanabe E, Yamane T, Yamashita S, Aonuma K: Clinical experience of idarucizumab use in cases of cardiac tamponade under uninterrupted anticoagulation of dabigatran during catheter ablation of atrial fibrillation. J Thromb Thrombolysis 47: 487-494, 2019.

17) Cappato R, Marchlinski FE, Hohnloser SH, Naccarelli GV, Xiang J, Wilber DJ, Ma CS, Hess S, Wells DS, Juang G, Vijgen J, Hügl BJ, Balasubramaniam R, Chillou CD, Davies DW, Fields LE, Natale A, VENTURE-AF Investigators: Uninterrupted rivaroxaban vs. uninterrupted vitamin $\mathrm{K}$ antagonists for catheter ablation in non-valvular atrial fibrillation. Eur Heart J 36: 1805-1811, 2015.

18) Okumura $K$, Aonuma $K$, Kumagai $K$, Hirao $K$, Inoue $K$, Kimura M, Miyauchi Y, Tsushima E; JACRE Investigators: Efficacy and safety of rivaroxaban and warfarin in the perioperative period of catheter ablation for atrial fibrillation. Outcome analysis from a prospective multicenter registry study in Japan. Circ J 80: 2295-2301, 2016.

19) Kirchhof P, Haeusler KG, Blank B, De Bono J, Callans D, Elvan A, Fetsch T, Van Gelder IC, Gentlesk P, Grimaldi M, Hansen J, Hindricks G, Al-Khalidi HR, Massaro T, Mont L, Nielsen JC, Nölker G, Piccini JP, De Potter T, Scherr D, Schotten U, Themistoclakis S, Todd D, Vijgen J, Di Biase L: Apixaban in patients at risk of stroke undergoing atrial fibrillation ablation. Eur heart J 39: 2942-2955, 2018.

20) Kuwahara $T$, Abe $M$, Yamaki $M$, Fujieda $H$, Abe $Y$, Hashimoto K, Ishiba M, Sakai H, Hishikari K, Takigawa M, Okubo K, Takagi K, Tanaka Y, Nakajima J, Takahashi A: Apixaban versus warfarin for the prevention of periprocedural cerebral thromboembolism in atrial fibrillation ablation: Multicenter prospective randomized study. J Cardiovasc Electrophysiol 27: 549-554, 2016.

21) Takahashi N, Mukai Y, Kimura T, Yamaguchi K, Matsumoto $\mathrm{T}$, Origasa H, Okumura K: Efficacy and safety of uninterrupted periprocedural edoxaban in patients undergoing catheter ablation for atrial fibrillation. The Prospective KYURABLE Study. Circ J 83: 2017-2024, 2019.

22) Nakamura $K$, Naito S, Sasaki T, Take Y, Minami K, Kitagawa Y, Motoda H, Inoue M, Otsuka Y, Niijima K, Yamashita E, Sugai Y, Kumagai K, Koyama K, Funabashi N, Oshima S: Uninterrupted vs. interrupted periprocedural direct oral anticoagulants for catheter ablation of atrial fibrillation: A prospective randomized single-centre study on post-ablation thrombo-embolic and haemorrhagic events. Europace 21: 259-267, 2019. 